\title{
FDI in Multi-brand Retailing in India: Comparative study with China
}

\author{
Dr. Anuradha Jain \\ Associate Professor, Vivekananda Institute of Professional Studies \\ AU Block (Outer Ring Road) Pitampura Delhi - 110088
}

\section{ABSTRACT}

Retailing is the interface between the producer and the individual consumer buying for personal consumption. As such, retailing is the last link that connects the individual consumer with the manufacturing and distribution chain. Indian retail industry is one of the sunrise sectors with huge growth potential. However, in spite of the recent developments in retailing and its immense contribution to the economy, retailing continues to be the least evolved industries and the growth of organised retailing in India has been much slower as compared to rest of the world. This paper captures the existing retail scenario in India with regard to organized and un-organized retail and presents the limitations of the current set-up along with the experiences of domestic players. The paper discusses about opening up of the multibrand retail sector to foreign direct investment by the government. The rationale for retail reforms and challenges to be addressed by the retail sector are discussed. FDI in Retail is like an allopathic medicine - It would deliver quick results \& would not work as 'hit \& trial' like Homeopath. Government must go for Policy Mix to avoid its side effects. It will require various changes in internal policies also. The whole process must be made socially \& economically useful.It will be better to follow the Chinese model of caution and hurrying slowly. China took over 12years to liberalise its FDI regime and in stages with reversals as well. The Chinese retail environment is 20years ahead of us. Looking at their market today can give us a rough idea of how FDI in multi brand retail in India might pan out in the medium term and long term period.
Keywords: Organised retail, Globalization, Foreign Direct Investment, and Multi brand retail, China

\section{INTRODUCTION}

The problem of foreign investments in India has been an issue of outstanding importance ever since the days of the East India Company. It acquired a different complexion and added significance after Indian Independence. However, it was only after the launching of the Five Year Plans for comprehensive economic development and especially after 1991 policy of globalisation that this problem assumed a new dimension in economic thinking. Globalization is a factor which would catch and compete with other countries of the world in order to develop and prosper. Nobody would like to be immune from this facility. But it is also a hard fact that when economic stablisation and structural adjustment programs are taken up and free trade policy with uniformity of law starts, the rich becomes richer and poor become poorer. This is the negation of principle of socialism on the edifice of which the Indian constitution has been framed ${ }^{1}$. Globalization and liberalisation are inseparable. In India this policy of liberalization started in 1961 when Nehru was the Prime Minister. It could not keep pace because of the economic conditions of the country. As said by Prime Minister Dr. Manmohan Singh, 'In 1991, when we opened India to foreign investment in manufacturing, many were worried. But today, Indian companies are competing effectively both at home and abroad and they are investing around the world. I'm sure this will happen in retail trade

${ }^{1}$ Preamble to the Constitution of India. 
as well ${ }^{2}$. It was put into practice in 1991 and a system of globalization started when the economic condition of our country was in bad shape and socialistic influence of Russia had started eroding. According to International Monetary Fund, FDI is defined as "Investment that is made to acquire a lasting interest in an enterprise operating in an economy other than that of the investor, the investor's purpose being to have effective voice in the management of the enterprise" 3 .

Foreign Investment in India is governed by the FDI policy announced by the Government of India and the provision of the Foreign Exchange Management Act (FEMA) 1999. The Reserve Bank of India ( $\left(\mathrm{RBI}^{\circ}\right)$ in this regard had issued a notification, ${ }^{4}$ which contains the Foreign Exchange Management (Transfer or issue of security by a person resident outside India) Regulations, 2000. This notification has been amended from time to time. The Ministry of Commerce and Industry, Government of India is the nodal agency for motoring and reviewing the FDI policy on continued basis and changes in sectoral policy/ sectoral equity cap. The FDI policy is notified through Press Notes by the Secretariat for Industrial Assistance (SIA), Department of Industrial Policy and Promotion (DIPP).

It is generally accepted that foreign capital can register an impact on the economy of the recipient countries. But economists differ on the nature of this impact or the relative importance of the cost which the recipient countries have to incur or the benefits which they acquire. The problem of determining the exact role played by foreign investments in the economic growth of the borrowing countries has not been settled to the satisfaction of either the layman or the professional economist. Economic growth is closely related to growth of retailing. Economic

${ }^{2}$ Statement on FDI, published in Uday India, Oct 13, 2012. Pg 29.

${ }^{3}$ International Monetary Fund, Balance of Payments Manual, Washington, DC, 1977, pg. 408.

${ }^{4}$ Notification No. FEMA 20/2000-RB dated May 3,2000 . growth depends crucially on growth of the private consumption as it comprises of about two-thirds of the GDP. Retailing in India is one of the pillars of its economy and accounts for 14 to $15 \%$ of its $\mathrm{GDP}^{5}$. The growth of private consumption in turn depends on development of the retail industry. This linkage makes it imperative for the retail sector to experience high level of growth in order to have a sustainable economic growth In 2004, The High Court of Delhi ${ }^{6}$ defined the term retail's a sale for final consumption in contrast to a sale for further sale or processing (i.e. wholesale).' $A$ sale to the ultimate consumer'.

The retail sector in India has undergone significant transformation in the past 10 years. Traditionally, Indian retail has been characterized by the presence of a large number of small unorganized retailers. However, in the past decade organized retail has developed rapidly, which has encouraged large private sector players to invest in this sector. Many foreign players have also entered India through different routes such as franchising, wholesale, cash and carry etc. With high GDP growth, increased consumerism and liberalization of the manufacturing sector, India is being portrayed as an attractive destination for FDI in multi-brand retailing. However, at present this sector is closed to FDI. Within the country there has been significant protest from trading associations and other stakeholders against allowing FDI in multi-brand retail. To make things easier, we could look at China, which like India has historically had a vast and fragmented retail sector ${ }^{7}$. It will be better to follow the Chinese model of caution and hurrying slowly. China took over 12years to liberalise its FDI regime and in stages with reversals as well. The

${ }^{5}$ Anand Dikshit,"The Uneasy Compromise Indian Retail". The Wall Street Journal August 12, 2011.

${ }^{6}$ Association of Traders of Maharashtra v. Union of India, 2005 (79) DRJ 426

${ }^{7}$ Guruswamy, Mohan, Sharma, Kamal Mohanty, Jeevan Prakash and Korah, Thomas J. 2005. FDI in India's Retail Sector: More Bad than Good, Economic and Political Weekly. Vol. 40, no. 7: 619-623. 
Chinese retail environment is 20years ahead of us. Looking at their market today can give us a rough idea of how FDI in multi brand retail in India might pan out in the medium term and long term period.

As part of integrating Indian economy to world market due to WTO obligation and also for encouraging foreign direct investment (FDI) in the country, Government of India proposed a policy of 100 per cent FDI in single brand retail, and 51 per cent FDI in multi-brand retail ${ }^{8}$. According to the proposed provisions, the minimum foreign investment shall be $\$ 100$ million, of which at least half shall be for back end infrastructure creation. It is argued that with this single stroke, multi-billion dollar enterprises may set up their stores in India, which may 'revolutionize' the retail sector.

One cannot forget that the Indian retail industry has experienced high growth over the last decade with a noticeable shift towards organised retailing formats. The industry is moving towards a modern concept of retailing. It has been ranked at the third place in global FDI in 2009, following economic meltdown, will continue to remain among the top five attractive destinations for international investors. ${ }^{9}$ The size of India's retail market was estimated at US\$ 435 billion in 2010. Of this, US\$ 414 billion (95 per cent of the market) was traditional retail and US $\$ 21$ billion (5 per cent of the market) was organized retail. India's retail market is expected to grow at 7 per cent over the next 10 years, reaching a size of US $\$ 850$ billion by 2020 . Traditional retail is expected to grow at 5 per cent and reach a size of US\$ 650 billion (76 per cent), while organized retail is expected to grow at 25 per cent and reach a size of US\$ 200 billion by $2020 .^{10}$

The US based global management consulting firm, AT Kearney, in its Global Retail Development Index (GRDI) 2011, has ranked India as the fourth most attractive nation for retail

\footnotetext{
${ }^{8}$ Proposed policy on FDI in Multi-brand

Retail.para 6.2.16.5 of press note 5(2012 series), Government of India.

${ }^{9}$ World Investment Prospects Survey 2009-2011.

${ }^{10}$ FICCI report.
}

investment, among 30 emerging markets. As India's retail industry is aggressively expanding itself, great demand for real estate is being created. The cumulative retail demand for real estate across India is expected to reach 43 million square feet by 2013. Around 46 per cent of the total estimated demand between 2009 and 2013 will come from Tier-1 cities. For instance, Pantaloon Retail added 2.26 million square feet (sq. ft.) of retail space during the fiscal 2011 and booked over 9 million sq. $\mathrm{ft}$ of retail space to fructify its expansion plans in future. ${ }^{11}$

As a concept people don't oppose FDI but FDI cannot be granted as a cardinal principle to access anything and everything. This is the main difference amongst various political parties. They have now introduced the FDI in retail. And FDI in multi-brand retail as per some conviction is a low priority at this stage of our economy because of the experience of the FDI in retail sector. First retail chain is not a big technology where one may have ample retail or more retail actually. After agriculture this is the single most employment provider of the economy with 40 million of people being directly or indirectly involved into it. So this is the third largest employer of the economy. They are not demanding jobs from the government. And the retail shop or the corner kiraana shops, as we know, are doing a laudable service. India is not facing a service deficiency as far as retail is concerned. We have already allowed organised retail. Some were opposing that also but didn't oppose the organized retail. Its' okay if we have to modernise the retail, we have to view the scale which it requires. And now we have been a decade into the organised retail and organised retail is actually facing many problems nowadays. So there was a demand from the organised retail. There is a heavy burden of price-rise on the shoulder of the people. A heavy economic dose in the shape of controlling and enhancing diesel and petroleum product prices would weigh heavy on them. ${ }^{12}$ People want economic reform for the

\footnotetext{
${ }^{11}$ A.T. Kearney Report on FDI Confidence Index

${ }^{12}$ Times of India(Delhi),12 December,2012 pg 1
} 
country but not heavy dose which they cannot be economic reform for the country but not heavy dose which they cannot bear. Retail sector is of utmost importance in case of Indian economy and to prove it we must see the SWOT analysis of it.

SWOT Analysis of Retail sector

\section{Strength}

a. Major Contribution to GDP: the retail sector in India is hovering around $33-35 \%$ of GDP as compared to around $20 \%$ in USA

b. High Growth Rate: the retail sector in India enjoys an extremely high growth rate of approximately $46 \%$.

c. High Potential: since the organised portion of retail sector is only $2-3 \%$, thereby creating lot of potential for future players.

d. High Employment Generator: the retail sector employs $7 \%$ of work force in India, which is right now limited to unorganised sector only. Once the reforms get implemented this percentage is likely to increase substantially.

\section{WEAKNESSES}

a. Lack of Competitors: AT Kearney's study on global retailing trends found that India is least competitive as well as least saturated markets of the world.

b. Highly Unorganised: The unorganised portion of retail sector is only $97 \%$ as compared to US, which is only $20 \%$.

c. Low Productivity: Mckinsey study claims retail productivity in India is very low as compared to its international peers.

d. Shortage of Talented Professionals: the retail trade business in India is not considered as reputed profession and is mostly carried out by the family members (self-employment and captive business). Such people are not academically and professionally qualified.

e. No = Industry status, hence creating financial issues for retailers: the retail sector in India does not enjoy industry status in India, thereby making difficult for retailers to raise funds. 26

\section{OPPORTUNITIES (benefits)}

a. There will be more organization in the sector: Organized retail will need more workers. According to findings of KPMG , in China, the employment in both retail and wholesale trade increased from $4 \%$ in 1992 to about $7 \%$ in 2001, post reforms and innovative competition in retail sector in that country.

b. Healthy Competition will be boosted and there will be a check on the prices (inflation):Retail giants such as Walmart, Carrefour, Tesco, Target and other global retail companies already have operations in other countries for over 30 years. Until now, they have not at all become monopolies rather they have managed to keep a check on the food inflation through their healthy competitive practices.

c. Create transparency in the system: the intermediaries operating as per mandi norms do not have transparency in their pricing. According to some of the reports, an average Indian farmer realises only onethird of the price, which the final consumer pays.

d. Intermediaries and mandi system will be evicted, hence directly benefiting the farmers and producers: the prices of commodities will automatically be checked. For example, according to Business Standard, Walmart has introduced -Direct Farm Projectll at Haider Nagar in Punjab where 110 farmers have been connected with Bharti Walmart for sourcing fresh vegetables directly.

e. Quality Control and Control over Leakage and Wastage: due to organisation of the sector, $40 \%$ of the production does not reach the ultimate consumer. According to the news in Times of India, $42 \%$ of the children below the age group of 5 are malnourished and Prime Minister Dr.Manmohan Singh has termed it as -national shame. Food often gets rot in farm, in transit and in state-run warehouses. Cost conscious and highly competitive retailers will try to avoid these wastages and losses and it will be their endeavor to make quality products 
available at lowest prices, hence making food available to weakest and poorest segment of Indian society.

f. Heavy flow of capital will help in building up the infrastructure for the growing population: India is already operating in budgetary deficit. Neither the government of India nor domestic investors are capable of satisfying the growing needs (school, hospitals, transport etc.) of the ever growing Indian population. Hence foreign capital inflow will enable us to create a heavy capital base.

g. There will be sustainable development and many other economic issues will be focused upon. Many Indian small shops are not under any contract and also under aged workers giving rise to child-labour. It also boosts corruption and black money.

\section{THREATS}

a. Current Independent Stores will be compelled to close: This will lead to massive job loss as most of the operations in big stores like Walmart are highly automated requiring fewer work forces.

b. Big players can knock-out competition: they can afford to lower prices in initial stages, become monopoly and then raise price later.

c. India does not need foreign retailers: as they can satisfy the whole domestic demand.

d. Remember East India Company it entered India as trader and then took over politically.

e. The government hasn't been able to build consensus.

f. In view of the above analysis, if we try to balance opportunities and prospects attached to the given economic reforms, it will definitely cause good to Indian economy and consequently to public at large, if once implemented. All the above mentioned drawbacks are mostly politically created. With the implementation of this policy all stakeholders will benefit whether it is consumer through quality products at low price, farmers through more transparency in trading or Indian corporate with 49\% profit share remaining with Indian companies only.

China used to be one of the most closed economies in terms of policy toward foreign investment and external debt. Starting from virtually no foreign-owned firms on Chinese soil before 1979, China has now become one of the largest developing host countries for foreign investment with the flow of foreign direct investment (FDI) reaching $\$ 26$ billion (U.S.) in $1993^{13}$. This dramatic change is part of the overall Chinese effort that began about 20 years ago to reform the economic system and open up to the outside world.

China opened up FDI in retail only in 1992 and that was limited to 26 per cent. Ten years later, in 2002, that cap was raised to 49 per cent. It was only in 2004 that 100 per cent FDI in retail was allowed, after local Chinese manufacturing had acquired teeth ${ }^{14}$. Initially, China also allowed foreign retailers to open only in select metropolises, such as Beijing, Shanghai and Shenzhen, and moreover, only in certain districts in those cities. In Beijing and Shanghai, foreign retailers like Wal-Mart were only allowed to operate in districts where there were no local competitors. Through these "invisible barriers", China succeeded in giving local retailers protection, while at the same time, they learnt from the "more efficient" business models of foreign companies. ${ }^{15}$

China, in fact, is a really exciting example of how it transformed Walmart USA. As China ramped up its own manufacturing sector, through subsidies, special economic zones and other perks, as many as 15,000 Chinese suppliers were serving Walmart China in 2010; the company had

\footnotetext{
${ }^{13}$ China State Statistics Bureau 1994

${ }^{14}$ Dutta, Devangshu. 2011. FDI in Retail: More Heat than Light. [Newspaper article online]. Financial Express: FE Reflect, Saturday, 26 November. Accessed on 23 March 2012 at

http://www.financialexpress.com/news/more-heat-thanlight/880586/

${ }^{15}$ Krishnan, Ananth, Chinese retailers give global giants run for money. The Hindu, Friday, 2 December, 2012.
} 
expanded its presence to 352 supermarkets in 130 cities across China. Exports to the US amounted to $\$ 60$ billion annually. Walmart China now claims that 95 per cent of its goods sold in China are sourced locally.

China achieved an impressive economic growth with an average rate over $9 \%$ in 1978-2005, the highest in that period. The achievement seems to owe much to the adoption of radical initiatives encouraging inward FDI. From an almost isolated economy, China has become the largest FDI recipient in the developing world and globally the second largest (next to US) since 1992. In 2002, China even surpassed the US with FDI inflows of $\$ 53$ billion. By the end of 2005, the accumulated FDI in China was $\$ 622$ billion. The contribution of FDI to the Chinese economy seems to be burgeoned in ways that no one anticipated. In 2004, FDI inflows constituted $7 \%$ of the gross capital formation. The overall number of foreign retail stores in China in the Top 100 increased by $25.64 \%$, exceeding the $11.49 \%$ of Chinese retail stores in 2010. There were 135 newly-opened stores of the six major foreign supermarket operators in 2010 , up $22.77 \%$ over the previous year. Seven foreign retailers enjoyed the growth of more than $20 \%$ in the number of stores in $2010^{16}$. This means burgeoning organised retail segment; and the benefits of a larger organised retail segment are several -the greater benefit being the expanded reach and increased volumes that organised retail can tap. Increased volumes translate into more manufacturing, more jobs in industry and more prosperity. Their sales greatly improved as well in 2010, but remained lower than the domestic average. Among the Top 100, foreign retailers had a sales growth of $18.09 \%$ in 2010 , vs. $25.3 \%$ sales growth of Chinese retailers. This is mainly because only $5 \%$ of China's retail enterprises are foreign invested and they still face restrictions and lack of clarity in rules ${ }^{17}$ (Woke

${ }^{16}$ Deloitte China CB\&T Group. 2011. China power of retailing 2011. [Report online]. China: Deloitte China Consumer Business \& Transportation (CB\&T) Group. Accessed on13 April 2012 at http://www.deloitte.com/assets/Dcom-

${ }^{17}$ Woke, Li. 2011. Robust domestic market is teeming with competitors. [Blog online]. China Daily. Accessed
2011). However, for one, it is unclear if India can pose the barriers that challenged foreign retailers in China, starting right from land - foreign retailers here have complained of not being given land by local governments, who control all land transactions in prime locations.

Certainly consolidation of the retail sector in China, as a result of the government-supported rise of local retail giants in order to protect them from foreign retailers, has put many small farmers who could not cope with lower prices, out of work. But it cannot be anyone's case that farmers are getting a good deal right now; they remain underprivileged in terms of accessing technology, inputs, and above all, credits and subsidies from the government in India. The fact is that farmers barely subsist while middlemen take the cream. Hence, we should not get dreamy about this unequal relationship and decline FDI in MBRT in the name of farmers' .Likewise, the argument that farmers will suffer once global retail has developed a virtual monopoly is also weak. Effect of FDI on Traditional Market in China

\begin{tabular}{|l|l|l|}
\hline Type & $\begin{array}{l}\text { No. of stores in } \\
\mathbf{1 9 9 6}\end{array}$ & $\begin{array}{l}\text { No. of stores in } \\
\mathbf{2 0 0 1}\end{array}$ \\
\hline Traditional & $1,920,604$ & $2,565,028$ \\
\hline Supermarkets & 13,079 & 152,194 \\
\hline Convenience & & 18,091 \\
\hline Hypermarkets & & 593 \\
\hline
\end{tabular}

Source: Foreign Direct Investment in Retail - ICICI Bank (2004)

There is a myth that organized global retailers eat up local retail chains including mom and pop stores. But in reality China brought in global retailers like Wal-Mart in 1996, has just about $20 \%$ of organized retail meaning the argument that unorganized retail gets decimated, is fallacious.

1. FDI in retailing was permitted in China for the first time in 1992. Foreign retailers were initially permitted to trade only in six Provinces and Special Economic Zones. Foreign ownership was initially restricted to $49 \%$.

on April 10, 2012 at

http://www.chinadaily.com.cn/business/201108/25/content_13188303.htm 
2. Foreign ownership restrictions have progressively been lifted and, and following China's accession to WTO, effective December, 2004, there are no equity restrictions.

3. Employment in the retail and wholesale trade increased from about $4 \%$ of the total labour force in 1992 to about 7\% in 2001. The numbers of traditional retailers were also increased by around $30 \%$ between 1996 and 2001.

4. In 2006, the total retail sale in China amounted to USD 785 billion, of which the share of organized retail amounted to $20 \%$.

5. Some of the changes which have occurred in China, following the liberalization of its retail sector, include:

a. Over 600 hypermarkets were opened between 1996 and 2001

b. The number of small outlets (equivalent to "kiranas"e) increased from 1.9 million to over 2.5 million.

c. Employment in the retail and wholesale sectors increased from 28 million people to 54 million people from 1992 to 2000

Shi Yongheng ${ }^{18}$ said that the success of China's local retailers was enabled by the government controlling the speed of the "gradual" opening up process, which gave local retailers enough time to adapt (Krishnan 2011). Apart from this, it is because of economic growth as well and also because big players' strengths in their home countries are based on factors that are totally absent in other countries, for instance, Wal-Mart is able to drive costs down because of its incredible logistics and supply chains which are absent in India as they were absent in China. There is also the question of physical infrastructure like roads and ports that are not to the same level as they are in the US and they simply will not have the kind of scale that they have in the US to negotiate and bargain with the suppliers and drive down the cost ${ }^{19}$

\footnotetext{
${ }^{18}$ Shi Yongheng is a professor from the School of Economics and Management at Tsinghua University who has studied China's retail sector

${ }^{19}$ Manshu, 2011, FDI in Multi Brand Retail is great. [Article online]. Economy, Tuesday, 29 November.
}

\section{CONCLUSION}

Like China, India should first encourage and focus on strengthening the domestic organised retail chains' foothold and presence in the multi brand retail sector prior to completely opening the multi brand retail to foreign investment. Our country also poses a big challenge to organised large retailers particularly in food sector. Food being perishable item, for the retailer to be successful the key is proper supply chain management. The challenge comes from a number of factors, e.g., huge size and population of our country, varied culture and hence varied taste, very poor infrastructure like improper roads, bad connectivity between production centre and markets, lack of proper cold chain facility like refrigerated transportation, ware-housing etc.

We had not set the stage ready for swallowing these reforms. The retailers were not mentally prepared for this competition. They were not given notice in advance. They are fearful that competition with fear is not a proper competition. It is presumed that the foreign investors would invest lavishly to make their shops attractive- the way potato chips in packets have become both costly and attractive. It would take time for Indian retailer to come to this position. Instead of giving them incentives at the times of economic crisis the government is pushing them to the wall. As said earlier, the retailers in India are not Ambanis, Tatas, Birlas, Laxmi Chand Mittal and the like. It is a poor lot. It needs to be trained in such market. If the retailers are given proper training and incentives it can compete in the market with the largest production and also marketing style in India.

I am a student of Economics \& so is the Prime Minister. The Prime Minister is entrenched in politics \& encircled with politicians. His timings of reforms are keeping with political expediency. He knows that pressure of the people would reduce the potency of the medicine. But a researcher is not a bargainer. Everyone wants development for the country and the masses.

Accessed on 7 March 2012 at

http://www.onemint.com/2011/11/29/fdi-in-multi-brandretail-is-great 
Sometimes, it is difficult to swallow a bitter pill \& if taken, it may lead to unpredictable consequences. Its potency must be bearable. It must be given not to save the doctor but the patients. FDI in Retail is like an allopathic medicine - It would deliver quick results \& would not work as 'hit \& trial' like Homeopath. Government must go for Policy Mix to avoid its side effects. It will require various changes in internal policies also. The whole process must be made socially \& economically useful.

\section{REFERENCES}

[1] Dutta, Devangshu. 2011. FDI in Retail: More Heat than Light. [Newspaper article online]. Financial Express: FE Reflect, Saturday, 26 November. Accessed on 23 March 2012 at http://www.financialexpress.com/news/mo re-heat-than-light/880586/

[2] Dikshit Anand,"The Uneasy Compromise - Indian Retail". The Wall Street Journal August 12, 2011.

[3] FDI: Issues in emerging economies, by K.Seehapathi

[4] FDI in Retail sector in India, by Arpita Mukherjee

[5] Government of India. 2010. Issue of Discussion Paper on Foreign Direct Investment (FDI) in Multi-Brand Retail Trading. Department of Industrial Policy and Promotion, Ministry of Commerce \& Industry.

[6] Guruswamy,and Korah, Thomas J. 2005. FDI in India's Retail Sector: More Bad than Good, Economic and Political Weekly. Vol. 40, no. 7: 619623.

[7] International Monetary Fund, Balance of Payments Manual, Washington, DC, 1977.

[8] Proposed policy on FDI in Multi-brand Retail.para 6.2.16.5 of press note 5(2012 series), Government of India.
[9] Singh, Sukhpal. 2011. FDI in Retail: Misplaced Expectations and Halftruths.Economic and Political Weekly. Vol. XLVI, no.51: 13-16.

[10] World Investment Prospects Survey 2009-2011 